\title{
Fat Digestion in the Newborn
}

\author{
CHARACTERIZATION OF LIPASE IN GASTRIC ASPIRATES \\ OF PREMATURE AND TERM INFANTS
}

\author{
Margit Hamosh, John W. Scanlon, Dvora Ganot, Melodie LiKel, \\ Kathleen B. Scanlon, and Paul Hamosh, Departments of Pediatrics and \\ Physiology and Biophysics, Georgetown University Medical Center, \\ Washington, D. C. 20007
}

A B STRACT We have measured lipolytic activity in gastric aspirates obtained at birth in a group of 142 infants. The infants ranged in gestational age from 26 to $41 \mathrm{wk}$. Lipolytic activity, measured by the hydrolysis of long chain triglyceride ([tri- $\left.{ }^{3} \mathrm{H}\right]$ oleate), and expressed as nanomoles FFA per milliliter gastric aspirate per minute was $333 \pm 66$ in 55 small premature infants (gestational age 26-34 wk and body wt 750$2,000 \mathrm{~g}$ ) and $558 \pm 45$ in a group of 87 larger infants (gestational age 35-41 wk and body wt 2,020-4,000 g). No activity was detected in seven infants with an unusually low $\mathrm{pH}$ in the gastric aspirate, $2.88 \pm 0.44$ (compared with a mean $\mathrm{pH}$ level of $5.59 \pm 0.22$ in the other 135 infants).

Attempts to characterize this lipase showed that it has a molecular weight of $44-48,000, \mathrm{pH}$ optimum of 3.0-5.0, that FFA acceptors (albumin) stimulate activity, whereas bile salts, taurocholate and glycocholate, cause marked inhibition at concentration $>3 \mathrm{mM}$. Our survey shows that enzyme activity is present as early as $26 \mathrm{wk}$ of gestation, increases with gestational age, and has the same characteristics throughout gestation. The data show that the lipase in gastric aspirates differs from pancreatic lipase, but closely resembles human and rat lingual lipase. Because the lipase has a low $\mathrm{pH}$ optimum and does not require bile salts, it can act in the stomach where it initiates the hydrolysis of dietary fat. We suggest that intragastric lipolysis is probably of major importance in the newborn and especially in the premature infant where it compensates not only for low pan-

This study was presented in part at the 64th Annual Meeting of the Physiological Society, Anaheim, Calif. April 1980, and published in abstract form (1980. Fed. Proc. 39: 1122).

Received for publication 11 August 1980 and in revised form 10 November 1980. creatic lipase, but in addition, helps to overcome the temporary bile salt deficiency through the formation of amphiphilic reaction products.

\section{INTRODUCTION}

The survival of infants with very low birth weight has increased substantially in the last few years. Normally this is a period of rapid intrauterine growth and development of the fetus. To maintain an adequate rate of growth the prematurely born infant suddenly becomes completely dependent upon the absorption of external nutrients. In addition, at birth, with the sudden transfer from the high-carbohydrate nutrition of the fetus (1) to the high-fat diet of the newborn, fat becomes the major energy source for the growing infant $(2,3)$.

Contrary to adults, who absorb $>95 \%$ of dietary fat, premature infants absorb only 65 to $80 \%$ of ingested fat (4). Inadequate lipid absorption in the preterm infant is attributed to low pancreatic lipase activity (5-7) and impaired solubilization of lipids due to low levels of bile salts (7-12). There are, however, marked variations in the efficiency of lipid absorption in the neonate that are attributed to variations in the functional maturity of the gastrointestinal tract at birth $(13,14)$. These individual differences in the ability to digest fat could be the result of variations in the level of intragastric lipolysis (15); infants in whom the latter mechanism is well developed could absorb fat more efficiently.

In man (16) and several other species (17) lipolysis is initiated in the stomach by a potent lipase secreted by lingual serous glands (von Ebner) (18-20). This lipase differs from pancreatic lipase in that it is relatively acid resistant, does not require bile salts for activation, and has a low $\mathrm{pH}$ optimum (3-5). Gastric digestion leads to the hydrolysis of $10-30 \%$ of the 
ingested fat to partial glycerides and FFA $(16,19,21)$. Recent animal studies have shown that the absence of oral secretions from the stomach causes a fall not only in intragastric lipolysis but also in the intestinal hydrolysis of dietary fat (22). The potential compensatory function of intragastric lipolysis in the premature infant resides not only in the hydrolysis of dietary fat, but also in the formation of amphiphilic reaction products (23) that could help to overcome the temporary bile salt deficiency. We have recently reported that considerable hydrolysis of dietary fat occurs in the stomach of newborn infants (24).The aim of the present study was to establish whether lipolytic activity is present at birth, whether it is found in very small premature infants and whether the characteristics of the lipase resemble those of recently purified rat lingual lipase (25).

\section{METHODS}

Subjects. 142 infants born between January and July 1979 were the subjects of this study. The infants had a birth weight range of 750 to $4,000 \mathrm{~g}$ and gestational age of 26 to $41 \mathrm{wk}$; all but eight infants were appropriate for gestational age.

Collection of samples. Gastric aspirates were obtained in the delivery room as part of the routine neonatal care. The volume of the samples was in the range of 0.3 to $6.0 \mathrm{ml}$. The specimens were immediately frozen and were kept at $-70^{\circ} \mathrm{C}$ until analysis 1-6 wk later. Under these storage conditions, lipolytic activity is stable for several months.

Assay of lipase activity. The lipolytic activity in all specimens was measured using a long chain triglyceride substrate, glyceryl ( $n=9.10,\left[{ }^{3} \mathrm{H}\right]$ oleate). A stable preparation of the triglyceride was made by emulsification of the labeled and carrier triolein in the presence of small amounts of polar lipids (lecithin, $4 \%$; monoolein, $1.3 \%$; oleic acid, $1.3 \%$; and cholesterol $0.65 \%$ ) as described in detail elsewhere (24).

The assay mixture contained in a final volume of $200 \mu \mathrm{l}$ : $1 \mu \mathrm{mol}$ of labeled triglyceride, $15 \mu \mathrm{mol}$ of sodium citrate buffer, pH 4.2, $6 \mathrm{mg}$ of bovine plasma albumin (Fraction V, Armour Pharmaceutical Company, Scottsdale, Ariz., lot N50402) and 10-25 $\mu$ l gastric aspirate. Incubation was for 60 min at $37^{\circ} \mathrm{C}$ in a Dubnoff shaking bath. For the screening of lipolytic activity, each specimen was assayed at $\mathrm{pH} 4.2$ (three aliquots of differing volume in order to have at least two determinations within the linear range) and at $\mathrm{pH} 8.1$ (sodium phosphate buffer, $15 \mu \mathrm{mol}$ per tube) to measure possible contamination by pancreatic lipase in regurgitated duodenal contents.

The reaction was stopped by the addition of $3.25 \mathrm{ml}$ of a mixture of methanol/chloroform/heptane (1.41:1.25:1, vol/vol/ vol). FFA were separated from glycerides by the addition of $1.05 \mathrm{ml}$ of potassium carbonate buffer, $0.05 \mathrm{M}, \mathrm{pH} 10.0$, as described by Belfrage and Vaughan (26). 1-ml aliquots of the aqueous phase were transferred to $10 \mathrm{ml}$ Hydromix scintillation fluid (Yorktown Research Co., Miami, Fla.) and the radioactivity was measured in a Beckman model LS-3150T scintillation spectrometer (Beckman Instruments, Inc., Fullerton, Calif.), using internal standards for quench correction.

Of total FFA $75-80 \%$ were present in the alkaline upper phase. Mixtures of nonradioactive triglyceride emulsion and $\left[{ }^{3} \mathrm{H}\right]$ oleic acid were used to determine the partition coefficient of FFA in the two phases. The partition of FFA be- tween the nonaqueous and aqueous phases was not affected by the following changes in the reaction mixture: type of buffer, $\mathrm{pH}$ of medium, or albumin concentration.

The triglyceride concentration of the substrate emulsion was quantitated by the hydroxamic acid method of Rapport and Alonzo (27).

Sephadex gel filtration. 200-300- $\mu$ l aliquots of gastric aspirate were applied to glass columns of Sephadex G-200, particle size 40 to $120 \mu \mathrm{m}$ (Pharmacia Fine Chemicals, Div. Pharmacia, Inc., Piscataway, N. J.). The columns were equilibrated with $0.9 \% \mathrm{NaCl}-0.25 \mathrm{M} \mathrm{KH}_{4} \mathrm{PO}_{4}-\mathrm{KOH}$ buffer, $\mathrm{pH}$ 6.3. The columns were run at room temperature; fractions of $0.5 \mathrm{ml}$ were collected into tubes kept in ice, and lipase activity was measured in $150-\mu$ l aliquots of each fraction. For the determination of molecular weight, the columns were calibrated with proteins of known molecular weight as described by Andrews (28). The elution patterns of the proteins was followed by determinations of optical density. The void volume was determined with blue dextran 2000 . The apparent molecular weight of the lipase in gastric aspirates was estimated from the linear plot of $K_{a v} v s$. the log of the molecular weight of known standards. $K_{a v}=\left(V_{e}-V_{0} V_{t}-V_{0}\right), V_{e}$ is the elution volume of the protein under investigation, $V_{0}$ is the void volume, and $V_{t}$ the total volume of the column.

\section{RESULTS}

Since gastric aspirates collected at birth contain considerable amounts of amniotic fluid, we have first tested whether lipase activity is present in amniotic fluid. Five specimens of amniotic fluid, obtained prior to premature or term delivery, had only traces of lipolytic activity, $10 \pm 3.2 \mathrm{nmol}$ FFA produced $/ \mathrm{ml}$ amniotic fluid per min in the lipase assay system at pH 4.2 and $0.70 \pm 0.40$ in the assay at pH 8.1. Contamination with amniotic fluid therefore cannot contribute lipolytic activity to gastric aspirates.

Regurgitation of duodenal fluid could lead to presence of pancreatic lipase in the stomach. To exclude this contaminating activity from our assay we first measured the $\mathrm{pH}$ optimum for lipolytic activity in adult human duodenal and gastric aspirates. As shown in Fig. $1 \mathrm{~A}$, in our assay system the $\mathrm{pH}$ optimum for lipolysis was 3.5-5.0 for gastric aspirate and 5.4-8.4 for duodenal aspirate. Because the lipase in gastric aspirate had optimal activity at $\mathrm{pH} 4.2$, whereas that in duodenal juice had only minimal activity at this $\mathrm{pH}$, we routinely measured lipolytic activity in gastric aspirates at $\mathrm{pH}$ 4.2. In addition, the lipolytic activity in each specimen was also tested at $\mathrm{pH} 8.1$ to evaluate the extent of duodenal contamination. Under our assay conditions, the lipolytic activity in gastric aspirates thus reflects true preduodenal activity i.e., gastric (29) and probably lingual lipase $(18,25)$.

Lipolytic activity was linear up to the production of $300 \mathrm{nmol}$ of FFA i.e., in the range of 5 to $20 \mu \mathrm{l}$ gastric aspirate.

Lipolytic activity in gastric aspirates. The results of the survey of 142 infants is presented in Table I and 


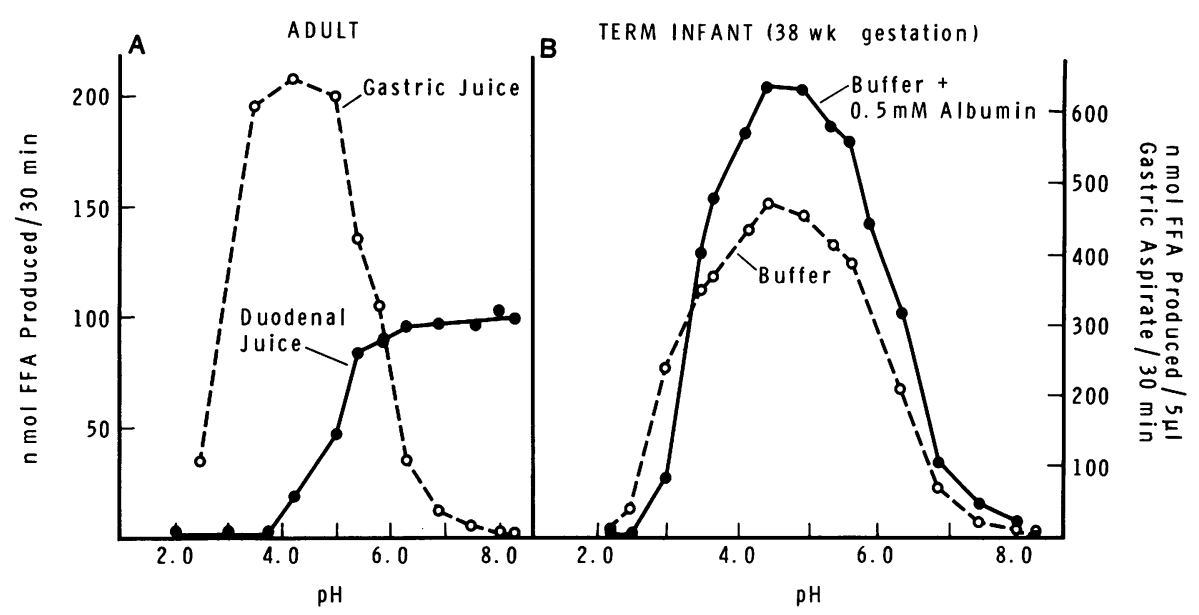

FIGURE 1 (A) Effect of $\mathrm{pH}$ on the lipolytic activity of adult human gastric $(O)$ and duodenal (O) juice. Lipolytic activity was tested in the $\mathrm{pH}$ range 2.2 to 8.3 . The buffers were glycine- $\mathrm{HCl}$ for $\mathrm{pH} 2.2$ to 3.5, sodium acetate-acetic acid for $\mathrm{pH} 3.7$ to 5.8, and phosphate buffer for pH 5.9 to 8.3. (B) Effect of $\mathrm{pH}$ and albumin $(0.5 \mathrm{mM})$ on the lipolytic activity in gastric aspirates of newborn infants. The buffers used for the $\mathrm{pH}$ range of 2.2 to 8.3 are as described above.

in the scattergram in Fig. 2. We have divided the infants into six groups based on gestational age and body weight. In the first group were nine infants of $26-28 \mathrm{wk}$ gestation, body weight was in the range of 750 to $1,000 \mathrm{~g}$. None of the infants in this group were small for gestational age and only one was delivered by cesarian section. Although this is a group of very small prematures, there was considerable lipolytic activity in the stomach, $321 \pm 117 \mathrm{nmol} \mathrm{FFA}$ produced/ml gastric aspirate per min. The very low level of activity at $\mathrm{pH} 8.1$ suggests that the lipase is of preduodenal origin. The data indicate that this lipase appears before $26 \mathrm{wk}$ of gestation in the human fetus and that it accumulates in the stomach before birth. The lipolytic activity re- mained at the same level in infants born between 29 and 34 wk of gestation, body wt range $1,000-2,000 \mathrm{~g}$ (groups 2 and 3 comprising 46 infants). Lipolytic activity was higher in infants of more advanced gestational age $608 \pm 34$ at $35 \mathrm{wk}, 564 \pm 62$ at $37 \mathrm{wk}$ and slightly lower, $501 \pm 41$ in term infants. Statistical analysis (Student's $t$ test) showed that the difference in lipolytic activity between infants of gestational age $<34$ wk was significantly different $(P<0.002)$ from that in infants of gestational age above $34 \mathrm{wk}$. In all age groups the lipolytic activity at $\mathrm{pH} 8.1$ amounted to $<7 \%$ of that measured at $\mathrm{pH} 4.2$. We were unable to detect lipolytic activity in seven infants; we do not know at present whether this is related to the unusually

TABLE I

Lipolytic Activity in Gastric Aspirates of Newborn Infants

\begin{tabular}{|c|c|c|c|c|c|c|c|}
\hline \multirow{3}{*}{$\begin{array}{l}\text { No. of } \\
\text { infants }\end{array}$} & \multirow{3}{*}{$\begin{array}{c}\text { Gestational } \\
\text { age }\end{array}$} & \multirow[b]{3}{*}{ Birth wt } & \multirow[b]{3}{*}{$\mathrm{SGA}^{*}$} & \multirow{3}{*}{$\begin{array}{c}\text { Cesarean } \\
\text { section }\end{array}$} & \multirow{3}{*}{$\begin{array}{c}\mathrm{pH} \text { of gastric } \\
\text { aspiration }\end{array}$} & \multirow{2}{*}{\multicolumn{2}{|c|}{$\frac{\text { Lipolytic activity }}{\text { nmol FFA/ml aspirate/min }}$}} \\
\hline & & & & & & & \\
\hline & & & & & & Assay $\mathrm{pH} 4.2$ & Assay pH 8.1 \\
\hline & $w k$ & $g$ & & & & & \\
\hline 9 & $27 \pm 0.5$ & $831 \pm 31$ & 0 & 1 & $5.56 \pm 0.5$ & $321 \pm 117$ & $20 \pm 6.3$ \\
\hline 22 & $32 \pm 0.4$ & $1,296 \pm 25$ & 3 & 0 & $5.74 \pm 0.3$ & $328 \pm 28$ & $21 \pm 2.5$ \\
\hline 24 & $34 \pm 0.4$ & $1,771 \pm 19$ & 3 & 3 & $5.70 \pm 0.19$ & $350 \pm 53$ & $23 \pm 3.2$ \\
\hline 35 & $35 \pm 0.2$ & $2,254 \pm 25$ & 2 & 4 & $6.25 \pm 0.12$ & $608 \pm 34$ & $42 \pm 3.9$ \\
\hline 22 & $37 \pm 0.3$ & $2,756 \pm 21$ & 0 & 3 & $5.36 \pm 0.30$ & $564 \pm 62$ & $34 \pm 6.4$ \\
\hline 30 & $39 \pm 0.2$ & $3,322 \pm 52$ & 0 & 4 & $4.93 \pm 0.17$ & $501 \pm 41$ & $32 \pm 3.3$ \\
\hline
\end{tabular}

Data are mean $\pm S E M$.

* Small for gestational age. 


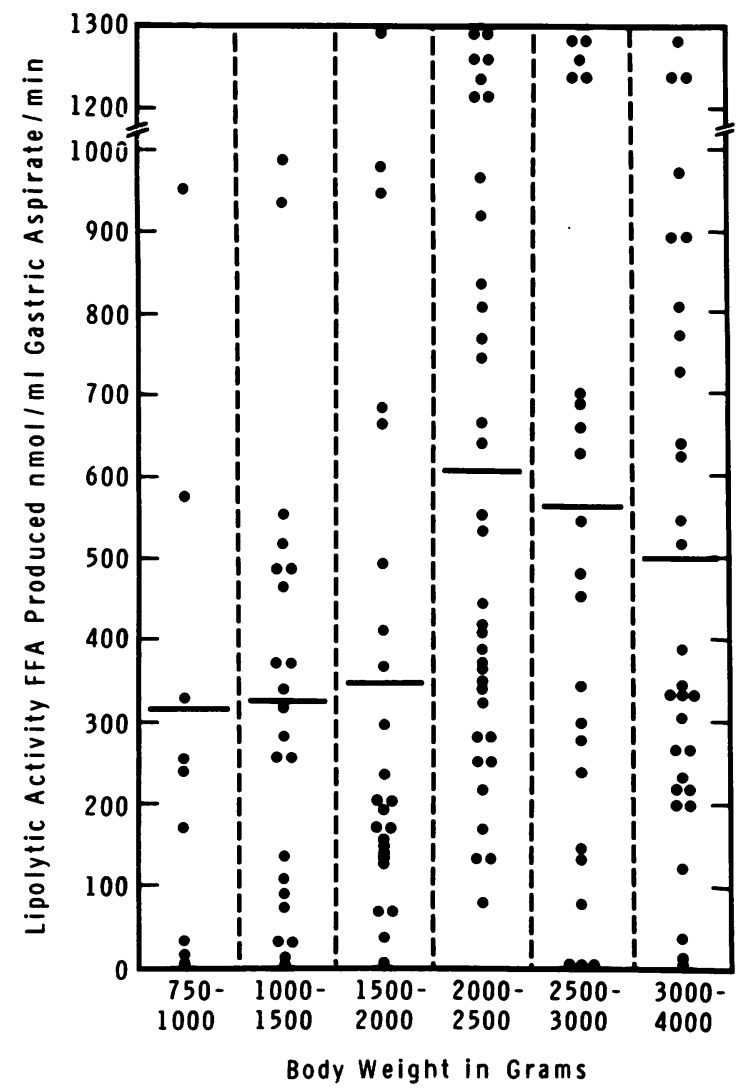

FIGURE 2 Lipolytic activity in gastric aspirates of newborn infants. The infants have been divided into six groups according to birth weight. The value of each individual infant is the mean of three separate determinations at $\mathrm{pH} 4.2$.

low $\mathrm{pH}$ of the gastric aspirates in these infants, range 1.5-4.0 mean 2.88 \pm 0.44 , compared to a mean $\mathrm{pH}$ of $5.50 \pm 0.22$ for the other 135 infants.

\section{Characterization of the lipolytic activity}

Gel filtration chromatography. The elution pattern of the lipase in two representative specimens of gastric aspirates (one from an infant of $34 \mathrm{wk}$ gestation, the other from an infant born at 36 wk gestation) is shown in Fig. 3. The apparent molecular weight was determined to be 44-48,000. Gastric aspirates from infants of various gestational ages (27-40 wk) showed a similar elution pattern on Sephadex G-200 columns, suggesting a similar molecular weight.

pH optimum and effect of albumin. In the adult, the $\mathrm{pH}$ of the stomach rises from a range of 2.0 to 2.5 before meals to 4.5 to 5.8 during, and immediately after feeding (30). In the newborn infant the $\mathrm{pH}$ of the stomach is between 3.0 and 5.0, 3-4 h after a meal and immediately preceding the next feeding (24); during

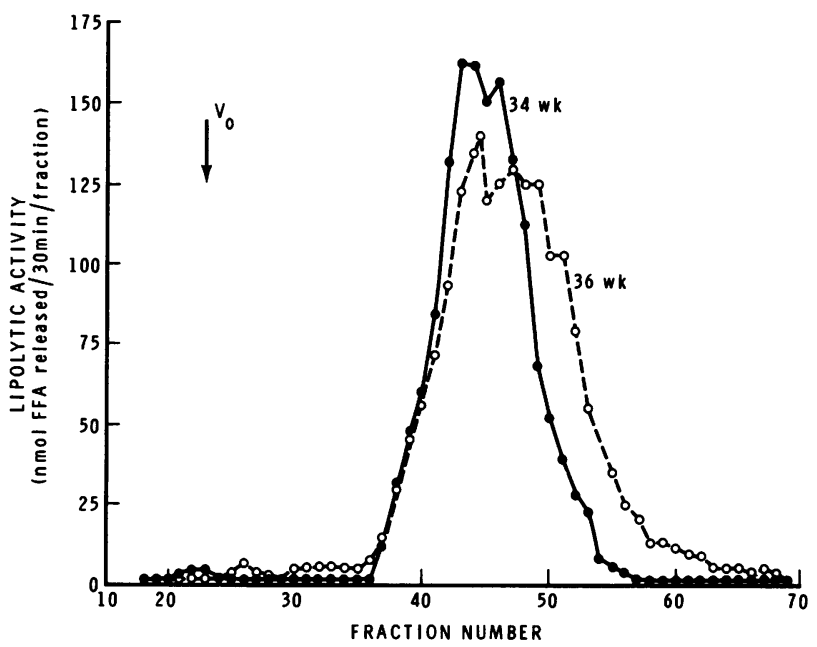

FIGURE 3 Evaluation of the apparent molecular weight of the lipase in gastric aspirates. Elution pattern of lipolytic activity on Sephadex G-200 columns $(1.5 \times 30 \mathrm{~cm}) .200-300$ $\mu l$ gastric aspirate was applied to the column. Fractions of $0.5 \mathrm{ml}$ were collected and lipolytic activity was measured in $150-\mu \mathrm{l}$ aliquots of each fraction. The void volume was determined with blue dextran; the column was calibrated with cytochrome $c\left(M_{\mathrm{r}}=12,500\right)$; egg albumin $\left(M_{\mathrm{r}}=45,000\right)$; bovine albumin $\left(M_{\mathrm{r}}=68,000\right)$; aldolase $\left(M_{\mathrm{r}}=158,000\right)$; catalase $\left(M_{\mathrm{r}}=240,000\right)$; and ferritin $\left(M_{\mathrm{r}}=450,000\right)$. The apparent molecular weight of the lipase in gastric aspirate is in the range of 44,000 to 48,000. Premature infant, $34 \mathrm{wk}$ gestation; P, term infant, 38 wk gestation.

and immediately after the meal it is between 5.0 and 5.5 (24). To hydrolyze dietary triglyceride in the stomach the lipase in gastric aspirates would have to have a $\mathrm{pH}$ optimum within this range. Indeed, as can be seen in Fig. 1, the lipolytic activity in representative specimens from adults (Fig. 1A) and new born infants (Fig. 1B) is in the range of 3.0 to 5.0. Albumin at a concentration of $0.5 \mathrm{mM}$ markedly stimulates lipolysis while at the same time slightly extending the $\mathrm{pH}$ optimum to 5.5 . These results indicate that in the $\mathrm{pH}$ range of 3.5 to 5.5 , the higher lipolytic activity probably reflects the more efficient removal of FFA by albumin. The sharp fall in activity above $\mathrm{pH} 6.0$ occurs both in the presence or absence of albumin.

Effect of bile salts on lipase activity. One would not expect a lipase active in the stomach to be dependent on bile salts for optimal activity. We have studied the effect of bile salts on the enzyme mainly in order to investigate whether the lipase could maintain some of its activity in the duodenum of the newborn, since in this age group the duodenal $\mathrm{pH}$ is lower than in the adult. The data presented in Fig. 4 show marked variations in the effect of different bile salts. Whereas at low concentrations $(1.5-3.0 \mathrm{mM})$ there is either no effect or a slight increase in lipolytic activity, 


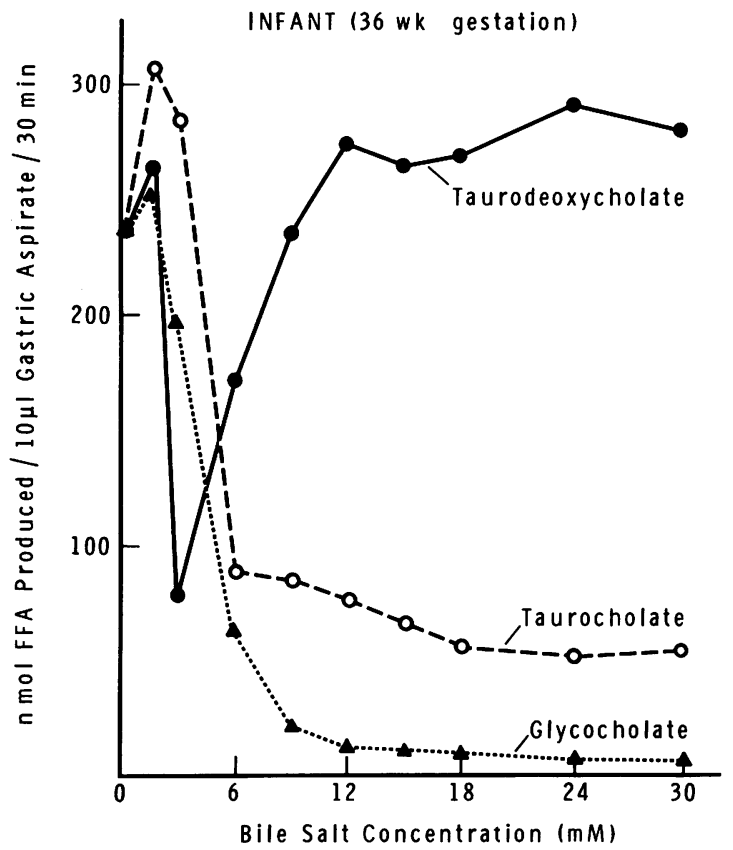

Figure 4 Effect of bile salts on lipolytic activity in gastric aspirates. Purified bile salts, taurocholate $(O)$, glycocholate (A) and taurodeoxycholate (O), 1.5-30 $\mathrm{mM}$ were incubated for $30 \mathrm{~min}$ with $10 \mu \mathrm{l}$ gastric aspirate in an assay system at pH 5.4 without albumin.

at concentrations higher than $6.0 \mathrm{mM}$, glycocholate and taurocholate severely inhibit lipolysis. Taurodeoxycholate exhibits a biphasic effect, inhibition in the range of 3.0 to $9.0 \mathrm{mM}$ and complete lack of inhibition at higher concentrations $(12-30 \mathrm{mM})$. Contrary to its effect on pancreatic lipase, purified colipase (a gift from Dr. J. S. Patton) does not prevent the inhibitory effect of bile salts on the lipase in gastric aspirates. The data suggest that bile salts, in the concentrations prevalent in the duodenum of the newborn infant $(1.5-2.0 \mathrm{mM})$, would not inhibit the lipolytic activity of gastric contents.

\section{DISCUSSION}

The rapid transition from the high fetal carbohydrate nutrition to the high fat diet (milk or milk substitutes) of the newborn necessitates well developed mechanisms of fat digestion and absorption. Fat digestion requires adequate lipase activity and bile salt levels, the former for the breakdown of triglycerides, the major component of dietary fat, the latter for proper emulsification of fat prior to and during lipolysis. In the newborn, especially the premature infant, pancreatic lipase levels (5-7) and bile salt concentrations are low (7-12), indicating that the newborn may depend on alternate mechanisms for the digestion of fat. Indeed, recent studies in man $(15,31,32)$ and earlier studies in several animal species (17) show that the newborn probably depends on extrapancreatic lipases for adequate fat digestion. Of special importance is intragastric lipolysis, where salivary (lingual) and gastric lipases probably compensate for low pancreatic lipase, whereas the products of lipolysis, fatty acids, and monoglycerides, compensate for low bile salt levels, by emulsifying the lipid mixture.

We have recently shown that as much as $15 \%$ of long chain triglycerides are hydrolyzed to partial glycerides and FFA within $7 \mathrm{~min}$ in the stomach of newborn infants (24). The rate of hydrolysis and the reaction products formed was similar to that reported previously for adult man (16) and rat (19). In our earlier study, which was limited to 13 infants of 30-34 wk gestational age, studied 4 to $22 \mathrm{~d}$ after birth, we have established that lipolytic activity is present in gastric aspirates, shortly after birth. The present study extends these observations to a group of 142 infants that range in gestational age from 26 to $40 \mathrm{wk}$. To investigate whether enzyme is present at birth, i.e., before feeding, all infants were studied immediately after delivery. An additional aim of the present study was to characterize the lipase in gastric aspirates of newborn infants. Contamination of gastric aspirates by regurgitated duodenal contents that may contain pancreatic lipase, could not be excluded; however, we tried to minimize the contribution of pancreatic lipase to the total lipolytic activity measured, by changing the $\mathrm{pH}$ in the assay system from $5.4(24)$ to 4.2 , a $\mathrm{pH}$ at which pancreatic lipase has only minimal activity (Fig. 1). In addition, lipolytic activity in each specimen of gastric aspirate was also tested at $\mathrm{pH} 8.1$ to measure the extent of contamination by pancreatic lipase (Table I). The latter did not amount to $>7.0 \%$ of the activity measured at $\mathrm{pH} 4.2$ (Table I).

Lipolytic activity was present in all age groups studied. Indeed a comparison of the activity levels in our previous group of 13 infants, which were studied several days to several weeks after birth (24) with the present group, in which gastric aspirates were obtained at birth, shows that the activity levels are several fold higher at birth. Whether this is due to accumulation of enzyme, with little loss to the duodenum before birth, as compared to passage of enzyme with each meal from the stomach to the duodenum after feeding, is not known at present. The higher enzyme level, even in very small premature infants (Table I, Fig. 2) suggests that the enzyme is present early during fetal development.

The $\mathrm{pH}$ of the gastric aspirates was between 5.0 and 6.0 in most of the premature infants and dropped slightly below 5.0 only at term (Table I). Several infants had very low pH values (mean for seven infants 
$2.88 \pm 0.44)$, in these cases we did not detect lipolytic activity probably because of inactivation (possibly peptic denaturation) of the enzyme of this low $\mathrm{pH}$.

Gel filtration chromatography on Sephadex G-200 columns showed that the lipolytic activity in gastric aspirates of infants of different gestational ages has a similar elution pattern. A representative example (Fig. 3) shows that the apparent molecular weight of the enzyme (in this case the gastric aspirates were from two infants of 34 and $36 \mathrm{wk}$ gestational age) is $44-48,000$. This molecular weight is almost identical to that of the lipase in adult human gastric juice (29) and to the low molecular weight species of rat lingual lipase (25). Indeed, the very small peak in the area of the void volume could be similar to the large molecular weight species of rat lingual lipase (25).

The $\mathrm{pH}$ optimum of the enzyme (3.0-5.5) suggests that it is ideally suited to act in the stomach, since the $\mathrm{pH}$ of gastric contents after the ingestion of a meal is in the same range of 3.5 to 5.5 .

Bile salts, taurocholic acid, the predominant bile acid in the newborn and glycocholic acid, the predominant bile acid 3-4 mo after birth $(33,34)$, in concentrations $>3 \mathrm{mM}$ markedly inhibit lipolysis. Because at lower concentration bile salts have either no effect or cause a slight stimulation, the lipase could remain active in the duodenum of the newborn because of their low concentration in newborns, especially premature infants, as well as because of the lower $\mathrm{pH}$ than in adults. Taurodeoxycholic acid inhibits lipolysis at concentrations of $3-9 \mathrm{mM}$, whereas no inhibition is seen at higher concentrations (up to $30 \mathrm{mM}$ ). Pure, commercially available bile salts (Calbiochem-Behring Corp., American Hoechst Corp., San Diego, Calif.) as well as bile salts that were purified by thin-layer chromatography had identical effects.

At present we do not know the origin of the lipase in the stomach; however, since lipolytic activity with similar characteristics is present in esophageal aspirates of infants with congenital esophageal atresia (31), we assume that in man, as has been shown in other species $(17,19,20)$ the lipase active in the stomach originates in lingual serous glands (18). A digestive lipase of oral origin presents several advantages for the newborn: oral structures and functions are well developed before birth (35); furthermore, the developmental pattern of lingual lipase differs markedly from that of pancreatic lipase. Although both enzymes are present in the fetus (36-38) pancreatic lipase activity is low at birth and remains low for several months in man (5-7) or until weaning in the rat, (39-40) whereas the lipase in human gastric aspirates (Table I and Fig. 2) and in rat lingual glands (41) rises throughout pre- and postnatal development. Fat digestion in the stomach probably is quanti- tatively much more important for the newborn than for the healthy adult: the stomach is a large receptacle where food is well mixed with enzymes through churning and squirting movements (42). Gastric emptying is delayed in the newborn (43), allowing for longer periods of food digestion than in adults. Furthermore, high fat concentration in gastric contents further delays gastric emptying.

Recent studies on suckling rats have shown that rapid intragastric hydrolysis of milk fat is followed by selective absorption of medium chain fatty acids $\left(\mathrm{C}_{8}-\right.$ $\mathrm{C}_{10}$ ) directly across the gastric mucosa (44). Because the lipolytic activity in gastric aspirates of premature infants is high, the efficient absorption of low birth weight formulas, which contain high concentrations of medium chain triglycerides, could be related to high intragastric lipolysis and direct absorption of medium chain fatty acids from the stomach.

Initial digestion within the stomach is especially important for milk fat because milk fat droplets are not a good substrate for pancreatic lipase $(22,29)$. Earlier studies by Cohen et al. (29) and recent studies in our laboratory (22) have shown that hydrolysis of milk fat is greatly enhanced by preincubation with human gastric aspirate or with rat lingual lipase, respectively. Furthermore, recent in vivo studies have shown that intragastric lipolysis markedly facilitates the intestinal digestion of dietary fat: after diversion of oral secretions from the stomach, there was a marked decrease $(50 \%)$ in intragastric hydrolysis of milk fat, followed by significantly lower intestinal lipolysis (60\% lower in the duodenum and $30 \%$ in the jejunum and ileum [22]).

The importance of intragastric lipolysis in premature infants, has recently been highlighted by the marked difference in fat absorption in nasogastrically vs. nasojejunally fed infants. A comparison of fat absorption in two groups of infants of $30 \mathrm{wk}$ gestational age showed lower fat excretion $(14.9 \pm 1.7 \%)$ in nasogastrically than in nasojejunally fed infants $(23.0 \pm 2.9 \%)(45)$.

The extent of intragastric lipolysis is probably affected by the nature of the fat and the fatty acid binding capacity of dietary proteins. The absence of complete hydrolysis, i.e., the formation of mainly di- and monoglycerides $(16,19,24,46)$, suggests that product inhibition probably determines the nature of the reaction products formed in the stomach after triglyceride ingestion. Product inhibition of pancreatic lipase is prevented by the removal of the FFA and their incorporation into micelles; bile salts and calcium ions play an important role in the formation of micelles and markedly affect the extent of intestinal hydrolysis of dietary fat (10). Since bile salts are not present in the stomach, the role of fatty acid acceptor during intragastric lipolysis is probably assumed by dietary pro- 
teins. However, the formation of almost identical reaction products, during in vivo lipolysis $(16,19,24$, 46 ), and in vitro in the absence of albumin (25), suggests that dietary proteins probably have only limited fatty acid binding capacity. The extensive studies on the number and affinity of fatty acid binding sites on the albumin molecule (47) are in marked contrast to the complete lack of information on the fatty acid binding ability of dietary proteins.

The nature of the proteins used in infant formulas could therefore be of great importance in regulating the degree of gastric lipolysis. A better understanding of the characteristics of these proteins could be of importance not only for nutritional considerations but also for clinical reasons. The highly efficient hydrolysis of the lipid in low birth weight formulas by lingual lipase (31) suggests that under certain conditions intragastric lipolysis may exceed the ability for fatty acid removal. The recent reports of nine cases of lactobezoars in premature infants fed a low birth weight infant formula $(48,49)$ suggests that the fatty acid binding ability of these proteins might not be adequate for the degree of gastric lipolysis.

The quantitative contribution of preduodenal lipolysis to the overall digestion of dietary fat in man and especially in the newborn cannot be evaluated at present. However, on the basis of data in other species $(17,37,50)$ and in light of the rapid fat hydrolysis in the stomach of infants (24) and adults (16) we suggest that intragastric lipolysis is probably of major importance in physiological and pathological conditions associated with low levels of pancreatic lipase such as prematurity, congenital absence of pancreatic lipase (51-53), or cystic fibrosis (54).

The compensatory role of intragastric lipolysis is evident in children with congenital absence of pancreatic lipase and in cystic fibrosis. Children with congenital absence of pancreatic lipase absorb as much as $60-70 \%$ of the ingested fat (53); since intragastric lipolysis is very high in these cases (51) one may assume that it compensates for the lack of pancreatic lipase.

It has long been recognized in patients of cystic fibrosis that in spite of pancreatic insufficiency a considerable amount of fat and protein is digested and absorbed; indeed, Ross and Sammons (55) have suggested that this is accomplished by lipolytic and proteolytic enzymes of extrapancreatic origin (55). Recent studies show that the gastric phase of fat digestion is preserved in cystic fibrosis patients with pancreatic insufficiency (56). Indeed, intragastric lipase activity is even elevated and associated with increased lipolysis. The higher lipolytic activity in gastric aspirates of newborn infants than in adults could be related to a similar compensatory mechanism.
The breast-fed newborn infant may depend on an additional mechanism for fat digestion, the bile salt stimulated lipase of human milk. This lipase found only in the milk of primates $(57,58)$, has a high $\mathrm{pH}$ optimum (7.0-8.0) and an absolute requirement for bile salts (58-66), suggesting that it acts in the intestine (61, 62). Recent studies have shown that the enyzme is stable at $\mathrm{pH} 3.5$, resists degradation in the stomach and requires bile salts for both its lipolytic activity and in order to resist tryptic degradation $(62,63)$. Although maximal activation of the enzyme requires bile salt concentrations that are higher than those in the duodenum of the premature newborn, high activity levels are achieved in the presence of primary bile salts also below their critical micellar concentration (63). Based on in vitro studies (62), it can be calculated that the activity of bile salt stimulated lipase is sufficient to completely hydrolyze milk triglycerides within $30 \mathrm{~min}$ in the small intestine.

Indeed, we $(31,64)$ and Williamson et al. (65) have recently observed higher absorption of fat in infants fed fresh (not heated) milk than in infants fed formula only (64) or heated breast milk (65). The presence of high levels of lipase in the milk of women who deliver prematurely (as early as $26 \mathrm{wk}$ of gestation) (66) suggests that fat digestion and absorption could be improved by feeding fresh breast milk to very small preterm infants.

\section{ACKNOWLEDGMENT}

We thank Miss Nancy Roberts and Miss Valerie Lee for secretarial help.

This study was supported by National Institutes of Health grants HD-10823 and AM-26641.

\section{REFERENCES}

1. Page, E. W. 1969. Human fetal nutrition and growth. Am. J. Obstet. Gynecol. 104: 378-387.

2. Hambraeus, L. 1977. Proprietory milk versus human breast milk in infant feeding. Pediatr. Clin. N. Am. 24: 17-36.

3. Hahn, P. 1972. Lipid metabolism and nutrition in the prenatal and postnatal period. In Nutrition and Development. Edited by M. Winick. John Wiley and Sons, New York. pp. 99-134.

4. Silverman, A., C. Roy, and F. J. Cozetti. 1971. Clinical pediatric gastroenterology. The C. V. Mosby Company, St. Louis. p. 512.

5. Delachaume-Salem, E., and H. Sarles, 1970. Evolution en fonction de l'age de la secretion pancreatique humaine normale. Biol. Gastro-Enterol. 2: 135-146.

6. Zoppi, G., G. Andreotti, F. Pajno-Ferrara, D. M. Njai, and D. Gaburro. 1972. Exocrine pancreas function in premature and full-term neonates. Pediatr. Res. 6: 880-886.

7. Norman, A., B. Strandvik, and O. Ojamae. 1972. Bile acids and pancreatic enzymes during absorption in the newborn. Acta Pediatr. Scand. 61: 571-576.

8. DeBelle, R. C., V. Vaupshas, B. B. Vitullo, L. R. Haber, 
E. Shaffer, G. G. Mackie, H. Owen, J. M. Little, and R. Lester. 1979. Intestinal absorption of bile salts: immature development in the newborn. J. Pediatr. 94: $472-476$.

9. Lester, R., R. A. Smallwood, J. M. Little, A. S. Brown, G. J. Piasecki, and B. T. Jackson. 1977. Fetal bile salt metabolism. The intestinal absorption of bile salt. J. Clin. Invest. 59: 1009-1016.

10. Watkins, J. B. 1975. Mechanism of fat absorption and the development of gastrointestinal function. Pediatr. Clin. N. Am. 22: 721-730.

11. Watkins, J. B., D. Ingall, P. Szezcepanik, P. D. Klein, and R. Lester. 1973. Bile salt metabolism in the newborn infant. Measurement of pool size and synthesis by stable isotopic technique. N. Engl. J. Med. 288: 431-434.

12. Watkins, J. B., P. Szezcepanik, J. B. Gould, P. Klein, and R. Lester. 1975. Bile salt kinetics in premature infants. An explanation for inefficient lipid absorption. Gastroenterology. 69: 706-713.

13. Grand, R. J., J. B. Watkins, and F. M. Torti, 1976. Development of the human gastrointestinal tract: a review. Gastroenterology. 70: 790-810.

14. Hamosh, M. 1981. The development of the metabolic and transport functions of the gastrointestinal system. In Biochemical Development of the Fetus and Neonate. C. Jones, editor. Elsevier North-Holland Biomedical Press, Amsterdam. In press.

15. Hamosh, M. 1979. Fat digestion in the newborn: role of lingual lipase and preduodenal digestion. Pediatr. Res. 13: $615-622$.

16. Hamosh, M., H. L. Klaeveman, R. O. Wolf, and R. O. Scow, 1975. Pharyngeal lipase and digestion of dietary triglyceride in man. J. Clin. Invest. 55: 908-913.

17. Nelson, J. H., R. G. Jensen, and R. E. Pitas, 1977. Pregastric esterase and other oral lipases. A review. J. Dairy Sci. 60: 327-362.

18. Hamosh, M., and W. A. Burns, 1977. Lipolytic activity of human lingual glands (Ebner). Lab. Invest. 37: 603-608.

19. Hamosh, M., and R. O. Scow. 1973. Lingual lipase and its role in the digestion of dietary fat. J. Clin. Invest. 52: 88-95.

20. Ramsey, H. A., G. H. Wise, and S. B. Tove, 1956. Estrolytic activity of certain alimentary tissues from cattle in different age groups. J. Dairy Sci. 39: 1312-1322.

21. Borgstrom, B., A. Dahlqvist, G. Lundh, and J. Sjovall. 1957. Studies of intestinal digestion and absorption in the human. J. Clin. Invest. 36: 1521-1536.

22. Plucinski, T. M., M. Hamosh, and P. Hamosh. 1979. Fat digestion in the rat: role of lingual lipase. Am. J. Physiol. 237: E541-E547.

23. Small, D. M. 1968. A classification of biologic lipids based upon their interaction in aqueous systems. J. Am. Oil Chem. Soc. 45: 108-117.

24. Hamosh, M., K. N. Sivasubramanian, C. Salzman-Mann, and P. Hamosh. 1978. Fat digestion in the stomach of premature infants. J. Pediatr. 93: 674-679.

25. Hamosh, M., D. Ganot, and P. Hamosh. 1979. Rat lingual lipase: characteristics of enzyme activity. J. Biol. Chem. 254: 12121-12125.

26. Belfrage, P., and M. Vaughan, 1969. Simple liquid-liquid partition system for isolation of labeled oleic acid from mixtures with glycerides. J. Lipid Res. 10: 341-344.

27. Rapport, M. M., and N. Alonzo, 1959. Photometric determination of fatty acid ester groups in phospholipids. J. Biol. Chem. 217: 193-198.

28. Andrews, P. 1966. Molecular-sieve chromatography. Br. Med. Bull. 22: 109-114.
29. Cohen, M., G. R. H. Morgan, and A. F. Hofmann, 1971 Lipolytic activity of human gastric and duodenal juice against medium and long-chain triglycerides. Gastroenterology. 60: 1-15.

30. James, A. H. 1957. The Physiology of Gastric Digestion. E. Arnold Publishers, Ltd., London. pp. 25-49.

31. Hamosh, M. 1979. The role of lingual lipase in neonatal fat digestion. In Development of Mammalian Absorptive Processes. J. T. Harries, editor. Ciba Foundation Series 70. Elsevier North-Holland Biomedical Press, Amsterdam. 69-98.

32. Fredrikzon, B., and O. Hernell, 1977. Role of feeding on lipase activity in gastric contents. Acta Paediatr. Scand. 66: 479-484.

33. Watkins, J. B. 1974. Bile acid metabolism and fat absorption in newborn infants. Pediatr. Clin. N. Am. 21: 501-512.

34. Roy, C. C., and A. M. Weber, 1977. Clinical implications of bile acids in paediatrics. Clin. Gastroenterol. 6: 377-395.

35. Bradley, R. M., and C. M. Mistretta, 1973. Swallowing in fetal sheep. Science. (Wash. D. C.). 179: 1016-1017.

36. Bradshaw, W. S., and W. J. Rutter. 1972. Multiple pancreatic lipases. Tissue distribution and pattern of accumulation during embriological development. Biochemistry. 11: 1517-1528.

37. Grosskopf, J. F. W. 1965. Study on salivary lipase in young ruminants. Onderstepoort J. Vet. Res. 32: 153-180.

38. Laitio, M., R. Lev, and D. Orlic. 1974. The developing human fetal pancreas: an ultrastructural and histochemical study with special reference to exocrine cells. J. Anat. 117: 619-634.

39. Deschodt-Lanckman, M., P. Robberecht, J. Camus, C. Baya, and J. Christophe. 1974. Hormonal and dietary adaptation of rat pancreatic hydrolases before and after weaning. Am. J. Physiol. 226: 39-44.

40. Koldovsky, O. 1969. Development of the Function of the Small Intestine in Mammals and Man. S. Karger, A. G., Basel.

41. Hamosh, M., and A. R. Hand. 1978. Development of secretory activity in serous cells of the rat tongue. Cytological differentiation and accumulation of lingual lipase. Devel. Biol. 65: 100-113.

42. Bloom, W., and D. W. Fawcett. 1968. A Textbook of Histology. 9th edition. W. B. Saunders Company, Philadelphia. pp. 513-521.

43. Signer, E., and R. Fridrich, 1975. Gastric emptying in newborns and young infants. Acta Paediatr. Scand. 64: 525-530.

44. Aw, T. Y., and M. R. Grigor. 1980. Digestion and absorption of milk triacylglycerols in 14 day old suckling rats. J. Nutr. 110: 2133-2140.

45. Roy, R. N., R. P. Pollinitz, J. R. Hamilton, and G. W. Chance. 1977. Impaired assimilation of nasojejunal feeds in healthy low-birth-weight newborn infants. J. Pediatr. 90: 431-434.

46. Helander, H. F., and T. Olivecrona, 1970. Lipolysis and lipid absorption in the stomach of the suckling rat. Gastroenterology. 59: 22-35.

47. Goodman, D. S. 1953. The interaction of human serum albumin with long-chain fatty anions. J. Am. Chem. Soc. 80: $3892-3898$.

48. Duritz, G., and C. Otlorf. 1979. Lactobezoar formation associated with high density caloric formula. Pediatrics. 63: 647-649.

49. Erenberg, A., R. D. Shaw, and D. Yousefzadeh. 1979. 
Lactobezoar in low-birth weight infant. Pediatrics. 63: 642-646.

50. Gooden, J. M., and A. K. Lascelles. 1973. Relative importance of pancreatic lipase and pregastric esterase in lipid absorption in calves 1-2 weeks of age. Aust. J. Biol. Sci. 26: 625-633.

51. Muller, D. P. R., J. P. K. McCollum, R. S. Trompeter, and J. T. Harries. 1975. Studies on the mechanism of fat absorption in congenital isolated lipase deficiency. Gut. 16: 838.

52. Rey, J., F. Frezal, P. Royer, and M. Lamy, 1966. L'absence congenitale de lipase pancreatique. Arch. Fr. Pediatr. 23: 5-14.

53. Sheldon, W. 1964. Congenital pancreatic lipase deficiency. Arch. Dis. Child. 39: 268-271.

54. Di Sant'Agnese, P. A., and R. C. Talamo. 1967. Pathogenesis and physiopathology of cystic fibrosis of the pancreas. N. Engl. J. Med. 277: 1287-1294, 1344-1352, 1399-1408.

55. Ross, C. A. C., and H. C. Sammons. 1955. Non-pancreatic lipase in children with pancreatic fibrosis. Arch. Dis. Child. 30: 428-431.

56. Roulet, M., A. M. Weber, Y. Paradis, C. C. Roy, R. LaSalle, and C. L. Morin. 1979. Gastric emptying and pharyngeal lipase activity in cystic fibrosis $(C F)$ patients. In Cystic Fibrosis Club Abstracts. pp. 11.

57. Freudenberg, E. 1953. Die Frauenmilch-Lipase. S. Karger, A. G., Basel.
58. Freudenberg, E. 1966. A lipase in the milk of the gorilla. Experientia (Basel). 22: 317.

59. Hernell, O., and T. Olivecrona, 1974. Human milk lipases. I. Bile salt stimulated lipase. J. Lipid Res. 15: 367-374.

60. Jubelin, J., and J. Boyer. 1972. The lipolytic activity of human milk. Eur. J. Clin. Invest. 2: 417-421.

61. Hall, B. 1980. Studies of lipase activity in human breast milk, using human milk as source of both enzyme and substrate. In Human Milk: Its Biological and Social Value. S. Freier, editor. Excerpta Medica, Amsterdam.

62. Hernell, O. 1975. Human milk lipases. III. Physiological implications of the bile salt stimulated lipase. Eur.J. Clin. Invest. 2: 267-272.

63. Fredrikzon, B., O. Hernell, L. Blackberg, and T. Olivecrona. 1978. Bile salt stimulated lipase in human milk: evidence of activity in vivo and of a role in the digestion of milk retinol esters. Pediatr. Res. 12: 1048-1052.

64. Alemi, B., M. Hamosh, J. W. Scanlon, and P. Hamosh. 1979. Fat digestion in very small premature infants: role of preduodenal lipases. Clin. Res. 27: 263A.

65. Williamson, S., E. Finucane, H. Ellis, and H. R. Gamsu. 1978. Effect of heat treatment of human milk on absorption of nitrogen, fat, sodium, calcium and phosphorus by preterm infants. Arch. Dis. Child. 53: 555-563.

66. Mehta, N. R., J. B. Jones, and M. Hamosh. 1981. Feeding the low birth weight infant: advantages of its own mother's milk. Crit. Care Med. In press. 